\title{
Post-larval development and sexual dimorphism of the spider crab Maja brachydactyla (Brachyura: Majidae)
}

\author{
GUILLERMO GUERAO and GUIOMAR ROTLLANT \\ IRTA, Unitat de Cultius Experimentals. Ctra. Poble Nou, km 5.5, 43540 Sant Carles de la Ràpita, Tarragona, Spain. \\ E-mail: guillermo.guerao@irta.cat
}

\begin{abstract}
SUMMARY: The post-larval development of the majid crab Maja brachydactyla Balss, 1922 was studied using laboratoryreared larvae obtained from adult individuals collected in the NE Atlantic. The morphology of the first juvenile stage is described in detail, while the most relevant morphological changes and sexual differentiation are highlighted for subsequent juvenile stages, until juvenile 8 . The characteristic carapace spines of the adult phase are present in the first juvenile stage, though with great differences in the degree of development and relative size. The carapace shows a high length/weight ratio, which becomes similar to that of adults at stage 7-8. Males and females can be distinguished from juvenile stage 4, based on sexual dimorphism in the pleopods and the presence of gonopores. In addition, the allometric growth of the pleon is sex-dependent from juvenile stage 4 , with females showing a positive allometry $(b=1.23)$ and males an isometric allometry $(b=1.02)$.
\end{abstract}

Keywords: Majidae, Maja brachydactyla, morphology, juvenile, post-larval development, growth, sexual dimorphism.

RESUMEN: Desarkollo postlarvario y dimorfismo seXual de Maja brachydactyla (Brachyura: Majidae). - El desarrollo postlarvario del májido Maja brachydactyla ha sido estudiado en el laboratorio después del cultivo larvario realizado a partir de individuos adultos capturados en el NE del Atlántico. La morfología del primer estadio juvenil se ha descrito en detalle y el desarrollo juvenil, hasta el estadio 8, ha sido estudiado en lo referente a los cambios morfológicos y la diferenciación sexual. En el primer juvenil, las espinas del cefalotórax características de los adultos están presentes, pero existen grandes diferencias en el grado de desarrollo y el tamaño relativo. El cociente longitud/anchura muestra valores elevados que tienden a parecerse a los de los adultos a partir del juvenil 7-8. Machos y hembras se pueden diferenciar a partir del cuarto estadio juvenil, según el dimorfismo sexual en los pleópodos y la presencia de gonoporos. Además, existen diferencias sexuales en el crecimiento alométrico del pleon a partir del cuarto estadio juvenil: las hembras muestran una alometría positiva ( $\mathrm{b}=1.23)$ y los machos muestran un crecimiento isométrico $(\mathrm{b}=1.02)$.

Palabras clave: Majidae, Maja brachydactyla, morfología, juvenil, desarrollo postlarvario, crecimiento, dimorfismo sexual.

\section{INTRODUCTION}

Many studies of larval development in crabs have produced extensive descriptions of the zoeal and megalopal developmental sequences. However, little is known about the post-larval development. Only a few studies have included partial to complete descriptions of at least the first juvenile stage (e.g. Ingle, 1977; Guerao et al., 2003, 2007; Luppi and Spivak, 2003). The available literature has shown that the acquisition of adult characters, including sexual differentiation, is highly variable within crabs (Shen, 1935; Payen, 1974; Ingle, 1977; Hebling et al., 1982; Felder et al., 1985; Fransozo, 1987; Fransozo and Negreiros-Fransozo, 1987; Rieger and Nakagawa, 1995; Flores et al., 1998, 2002; Rieger and Beltrão, 2000; Guimarães and Negreiros-Fransozo, 2005; Negreiros-Fransozo et al., 2007; Bolla Jr. et al., 2008).

Although the morphological characteristics of early juveniles have not usually been applied in 
taxonomic studies of crabs, a description of the early instars is necessary to assist in identification of juvenile stages of crabs collected in field studies (Ingle and Rice, 1984; Guimarães and NegreirosFransozo, 2005). In addition to elaborating useful identification keys, this information could be important for phylogenetic and phylogeographic studies.

Four species belonging to the genus Maja Lamarck, 1801 (Brachyura: Majoidea: Majidae) have been reported in Mediterranean and NE Atlantic waters: M. brachydactyla Balss, 1922, M. squinado (Herbst, 1788), M. crispata (Risso, 1827) and M. goltziana (d'Oliveira, 1888). M. brachydactyla is widely distributed in the NE Atlantic and the southern North Sea (Clark, 1986; d'Udekem d'Acoz, 1999; Neumann, 1998).

The morphology of M. brachydactyla larval stages has been studied by Schlegel (1911), Lebour (1927, 1928), Paula (1985), Clark (1986), Ingle (1992) and Guerao et al. (2008). In contrast, only a brief description of the carapace of three juvenile stages attributed to Maja brachydactyla (as M. squinado) is available (Lebour, 1927, 1928).

The aim of the present study is to provide a detailed morphological description, including sexual differentiation, of the post-larval development (juvenile stages 1-8) of $M$. brachydactyla reared in laboratory.

\section{MATERIAL AND METHODS}

Several adult specimens of $M$. brachydactyla were collected from the NE Atlantic (Ría de A Coruña, Galicia, NW Spain; $42^{\circ} 14^{\prime} \mathrm{N}, 8^{\circ} 40^{\prime} \mathrm{W}$ ) and brought to the IRTA (Sant Carles de la Ràpita, Tarragona, Spain) in February 2008. Once in the laboratory, crabs were kept in $2000 \mathrm{~L}$ tanks connected to a recirculation unit at a constant salinity and temperature of 36 and $18 \pm 2^{\circ} \mathrm{C}$, respectively, and fed on fresh mussel and frozen crab.

Larval rearing (60 larvae $\mathrm{L}^{-1}$ ) was carried out in 35-L, 150-um mesh-bottomed PVC cylinders (baskets) provided with sufficient aeration and air-lifts to renew the water inside the baskets. The baskets were immersed in 1500-L holding tanks that were kept at a constant salinity and temperature of 36 and $18 \pm$ $2^{\circ} \mathrm{C}$, respectively, under a natural light:dark cycle. Larvae were fed Artemia metanauplii (more details in Andrés et al., 2007).
After 17-20 days of larval culture, 100 juveniles (stage 1) were placed individually in methacrylate compartment boxes ( $50 \times 40 \times 45 \mathrm{~mm}$ ) connected to a recirculation circuit with partial renewal $(20 \%)$ of the water twice a week. A natural photoperiod (ca. 12:12 h light:darkness) was maintained and salinity and temperature were kept at 34 and $20 \pm 1{ }^{\circ} \mathrm{C}$, respectively. Juveniles were fed a combination of adult Artemia and frozen krill (Euphausiacea) once a day. The culture ended when juveniles were sexually differentiated and acquired a morphology similar to adults. The survival until the end of the experiment (juvenile stage 8 ) was $43 \%$.

Exuviae and specimens of each developmental stage were preserved in $70 \%$ ethanol or $10 \%$ formaldehyde. Exuviae were preferred for morphological examinations and measurements; for each stage, 5-20 individuals were used. Dissection and measurements were taken with a Nikon SMZ800 stereomicroscope equipped with an image analysing system (AnalySIS, SIS, Münster, Germany). Features of the appendages, after mounting in a polyvinyl medium, were observed under an Olympus BH-2 microscope.

For scanning electron microscopy (SEM), fresh material was fixed in 3\% glutaraldehyde for $3 \mathrm{~h}$ (see Felgenhauer, 1987), washed in three 5-min changes of distilled water, and sonicated for 1-3 min for removal of surface debris. Fixed specimens were dehydrated in a graded ethanol series $(30 \%, 50 \%$, $70 \%, 80 \%, 90 \% 100 \%$; three 5-min changes each). After critical-point-drying (BAL-TEC CPD 030), individuals were mounted on SEM stubs with selfadhesive carbon stickers. Dried specimens were observed with a HITACHI S-3500N SEM.

Carapace width $(\mathrm{CW})$ was measured as the greatest distance across the carapace measured between the tips of the 2 nd or $3 \mathrm{rd}$ branchial spines; postorbital spine length (POSL) was measured as the distance between the tips of the postorbital spines; carapace length (CL) was measured as the distance between the rostral margin (without rostral spines) and the posterior margin of the carapace (without intestinal spines); and pleon width (PW) was measured as the width of pleonite 6. Crab descriptions follow the basic malacostracan body pattern, starting with the most anterior somite and progressing towards the posterior ones. Each appendage is described from the proximal segments towards the distal segment. The long aesthetascs on the antennula and the long plumose setae on the distal exopod segments 
are drawn truncated. Figures 10 and 11 show only the pleopods of the left side.

The relative growth of body parts was determined using the allometric equation: $y=a x^{b}$. Using the $\log$ arithmic equations: $\log \mathrm{y}=\log \mathrm{a}+\mathrm{b} \log \mathrm{x}$, tests for departures from isometry $\left(\mathrm{H}_{\mathrm{o}}: \mathrm{b}=1\right)$ were performed on the slope values obtained using Student's $t$-test $(\alpha=0.01)$.

\section{RESULTS}

The first juvenile is described in detail and in later juvenile stages only the most relevant ontogenetic changes are described.

\section{Maja brachydactyla Balss, 1922}

(Figs 1-10)

\section{First juvenile}

Carapace (Figs. 1a, 2a and 3a). Longer than broad. Rostral and postorbital spines well-developed, POSL slightly longer than CW (CW/ POSL $<1)$. Preocular, supraocular, hepatic, branchial, and intestinal spines present and small. With a prominent cardiac tubercle. Gastric tubercles poorly developed. Surface with hooked setae.

Antennule (Fig. 1b). Peduncle 3-segmented, with 5,1,3 setae. Endopod 2-segmented, with 0,5 setae. Exopod 4-segmented, with 0,5,4,0 aesthetascs and 0,1,0,3-4 setae.

Antenna (Fig. 1c). Peduncle 3-segmented, with 6-7,2-3,3-4 setae, basal segment with two strong ventro-lateral spines and one dorsal tubercle. Flagellum 6-segmented, with 0,1,1-2,0,3,2 setae.

Mandible (Fig. 4). Molar portion reduced, incisor process saucer-shaped with acute margin. Palp 2 -segmented, with 5 setae on distal segment.

Maxillule (Fig. 5a). Coxal endite with 10 setae. Basial endite with 18 setae. Endopod unsegmented with 2-3 setae (2 terminal). Exopodal seta absent and epipodal seta present.

Maxilla (Fig. 5b). Coxal endite bilobed, with 5+5 setae. Basial endite bilobed, with $6+6$ setae. Endopod unsegmented, without setae. Exopod (scaphognathite) with 42-43 marginal plumose setae and 6-7 lateral setae.

First maxilliped (Fig. 5c). Epipod with 13-16 long setae. Coxal endite with 9-13 setae. Basial endite with 20-24 setae. Endopod unsegmented, and

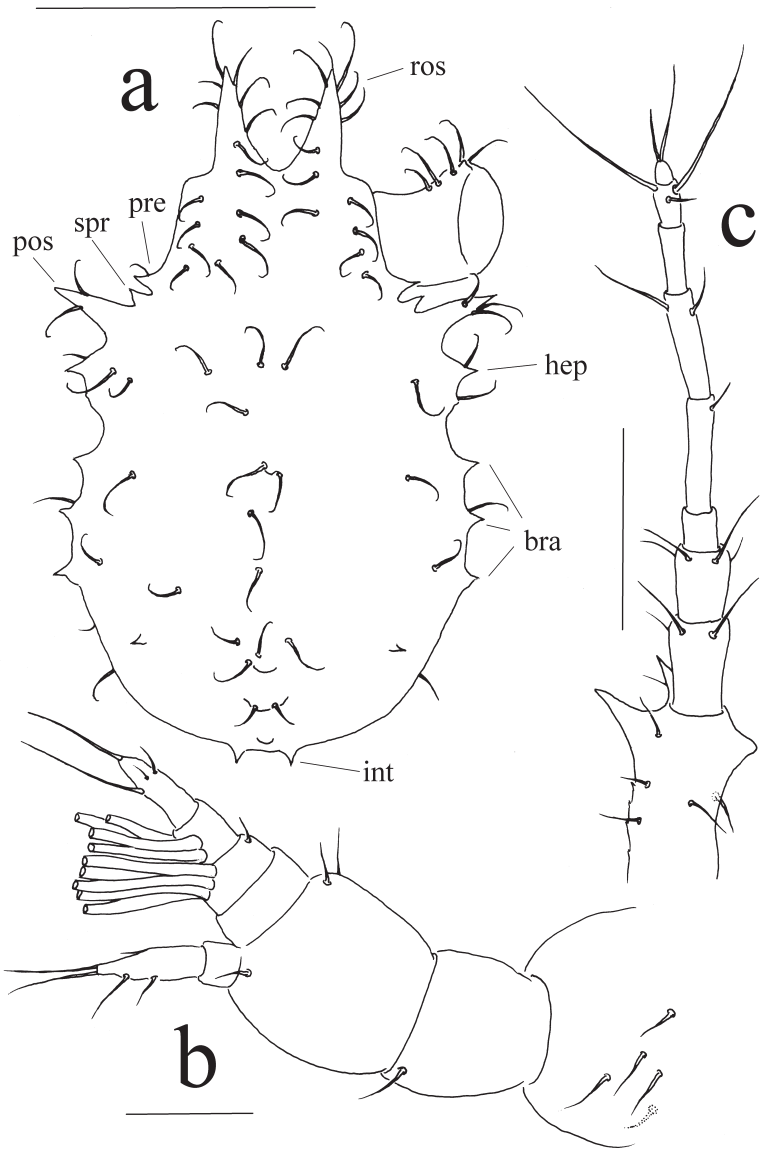

FIG. 1. - Maja brachydactyla Balss, 1922. First juvenile. a, carapace, dorsal view ; b, antennule ; c, antenna. Abbreviations: bra, branchial spines; hep, hepatic spine; int, intestinal spine; pos, postorbital spine; pre, preorbital spine; ros, rostral spine; spr, supraorbital spine. Scale bars: $\mathrm{a}=1 \mathrm{~mm} ; \mathrm{b}=100 \mu \mathrm{m} ; \mathrm{c}=200 \mu \mathrm{m}$.

with one long plumose seta and 3-4 simple setae. Exopod 2-segmented, proximal segment with 2 setae (one outer plumose seta + one simple inner seta); distal segment with one simple seta and terminal 4-5 plumose setae.

Second maxilliped (Fig. 5d). Endopod 5-segmented, with 1,2,1,6,7-8 setae. Exopod 2-segmented, proximal segment with 2 plumose setae and 3-4 simple setae. Distal segment with 1 simple seta and 6 plumose terminalsetae.

Third maxilliped (Fig. 6). Epipod with 13-15 setae (4-6 plumose + 9 long setae). Coxa with 10-13 setae; basis with 4 setae. Endopod 5-segmented, with 2119,6-9,10,9,6 setae; ischium inner margin with about 14 teeth; merus subovate, with 3 (two strong) and 3-5 teeth on inner and outer margin, respectively. Exopod 2-segmented, proximal segment with 6-7 setae, and distal segment with 6 plumose setae.

Pereiopods (Fig. 7b-f). Chelipeds with no ornamentation in palm; merus with 3 spines on outer 

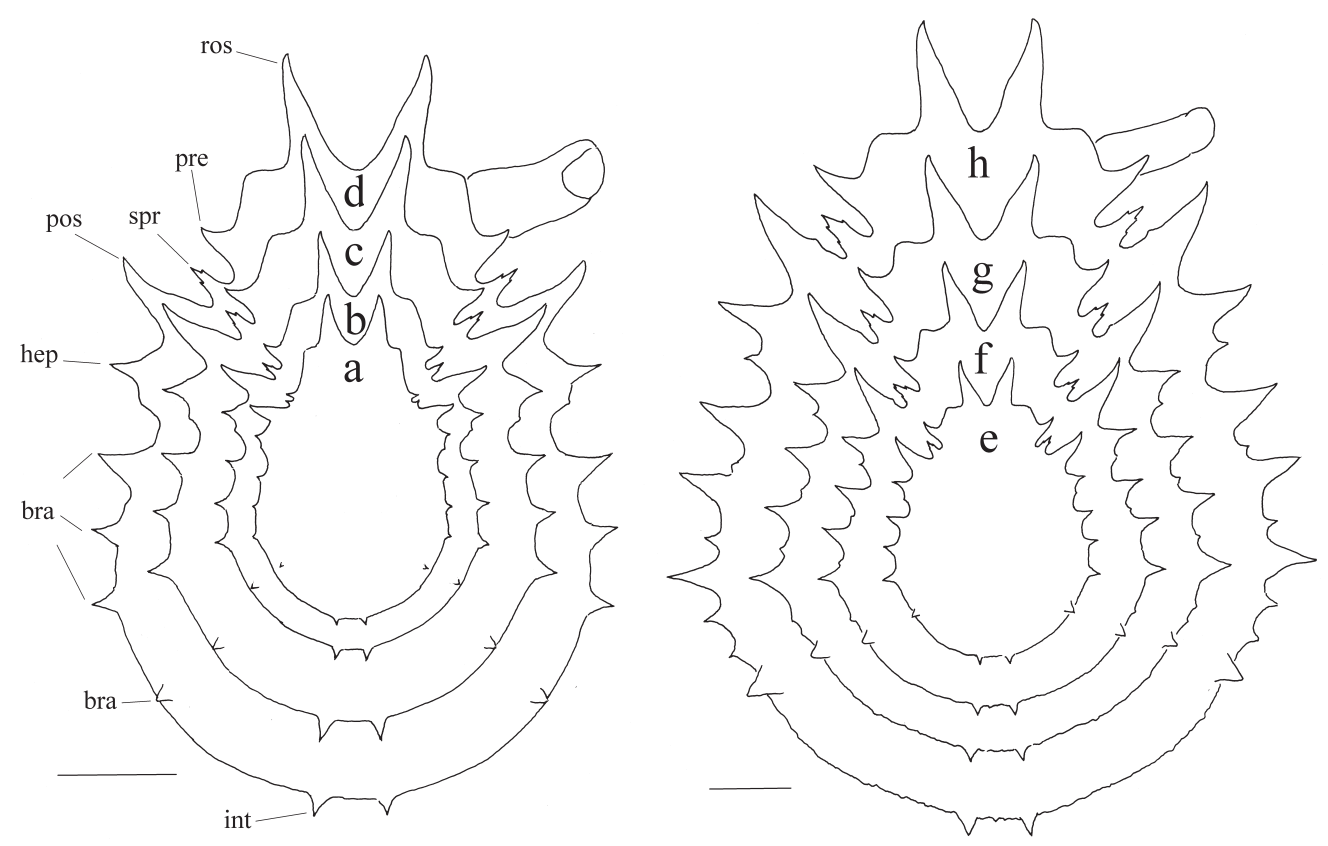

Fig. 2. - Maja brachydactyla Balss, 1922. Carapace shape. a-h, juvenile stages 1-8. Abbreviations: bra, branchial spines; int, intestinal spine; hep, hepatic spine; pos, postorbital spine; pre, preorbital spine; ros, rostral spine; spr, supraorbital spine. Scale bars: $\mathrm{a}-\mathrm{d}=4 \mathrm{~mm}$; e-h = $1 \mathrm{~mm}$.

margin; without hooked setae. Pereiopods 2-5 very setosed, with a terminal minute spine on outer terminal margin of the merus; merus, carpus and propodus with 3-6 hooked setae on outer margin.

Sternum (Fig. 7a). Anterior margin with teeth; condyles present on sternite 5. Setation as showed.

Pleon (Fig. 9a). Six somites and telson presents, broader than long; dorsoventrally flattened, flexed underneath the thorax and covered in sparsely setae; there is no apparent sex-related dimorphism in the relative dimensions of the juveniles examined; pleopods present in pleonites $2-5$, and uropods present in pleonite 6 , without setae.
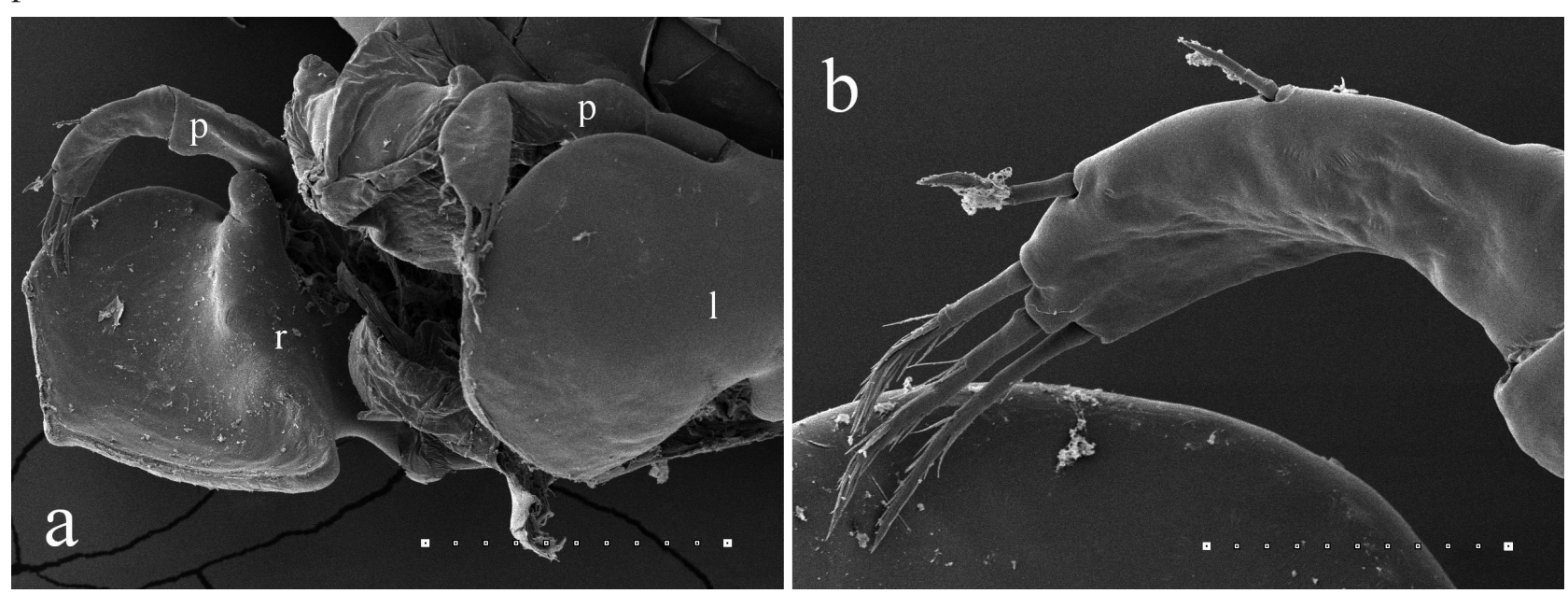

Fig. 4. - Maja brachydactyla Balss, 1922. First juvenile. a, mandible; b, magnification of terminal segment of mandibular palp. Abbreviations: 1, left mandible; $p$, mandibular palp; $r$, right mandible. Scale bars: $\mathrm{a}=200 \mu \mathrm{m} ; \mathrm{b}=50 \mu \mathrm{m}$.

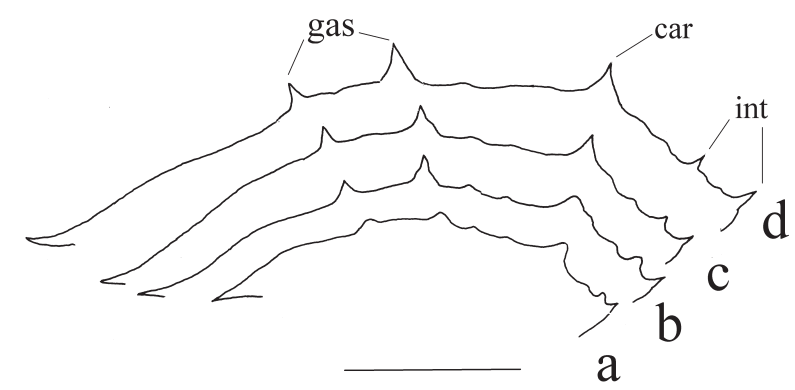

FIG. 3. - Maja brachydactyla Balss, 1922. Carapace shape, lateral view. a-d, juvenile stages 1-4. Abbreviations: car, cardiac spine; gas, gastric spine; int, intestinal spines. Scale bar $=1 \mathrm{~mm}$. 

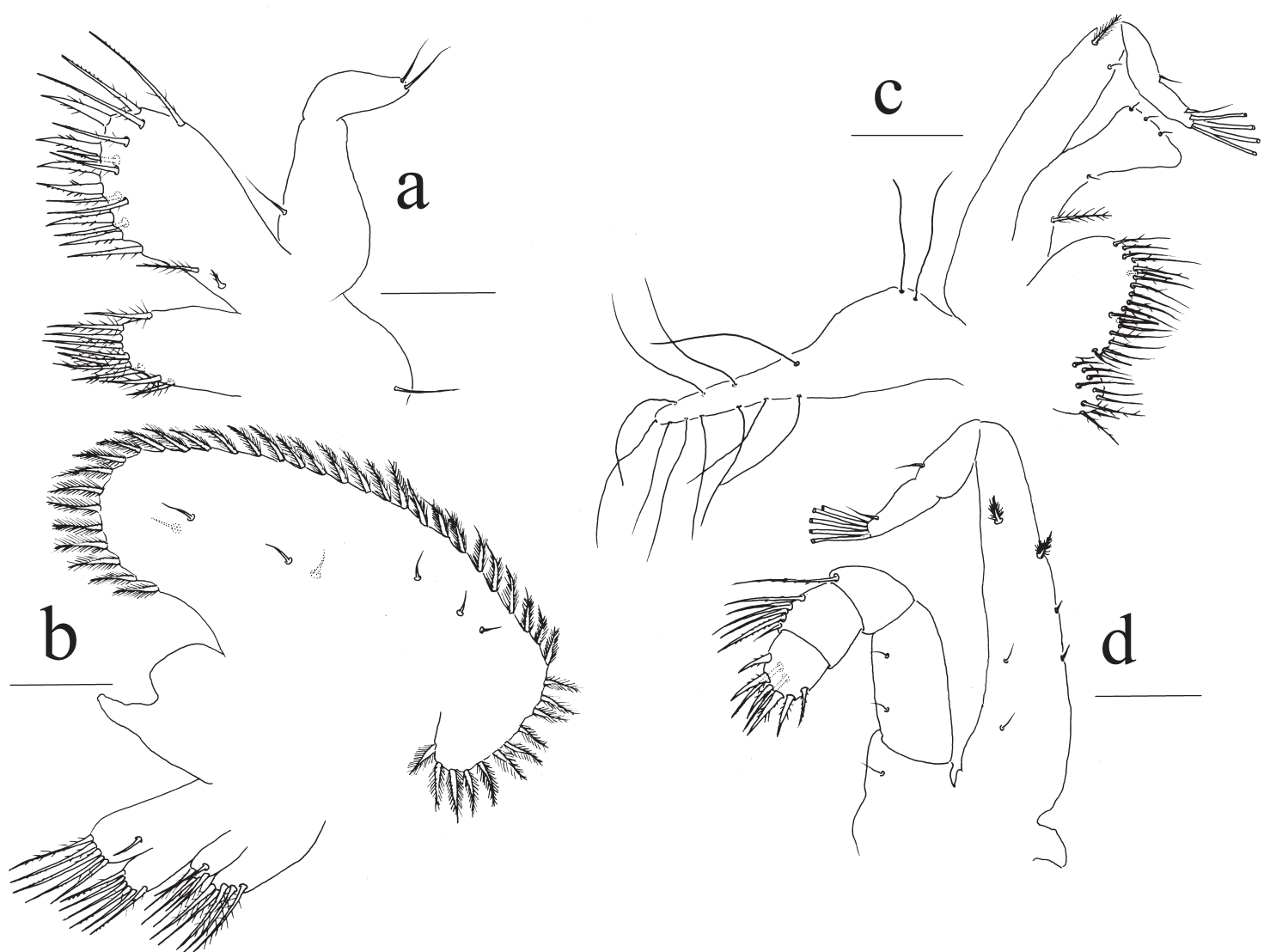

FIG. 5. - Maja brachydactyla Balss, 1922. First juvenile. a, maxillule; b, maxilla; c, first maxilliped; d, second maxilliped. Scale bars: a and b $=100 \mu \mathrm{m} ; \mathrm{c}$ and $\mathrm{d}=200 \mu \mathrm{m}$

TABLE 1. - Morphometrical and morphological characteristcs of early juvenile stages of Maja brachydactyla Balss, 1922 useful for their identification. Abbreviations: A, annulations; CL, carapace length; CW, carapace width; J, juvenile stage; ms, marginal setae; N, number of individuals studied; nf, not flagellated; POSL, postorbital spines length; Scaphog, scaphognathite; S, segments; s, setae.

\begin{tabular}{|c|c|c|c|c|c|c|c|c|}
\hline & $\mathrm{J} 1$ & $\mathrm{~J} 2$ & $\mathrm{~J} 3$ & $\mathrm{~J} 4$ & $\mathrm{~J} 5$ & J6 & $\mathrm{J} 7$ & $\mathrm{~J} 8$ \\
\hline $\mathrm{N}$ & 20 & 10 & 10 & 6 & 6 & 5 & 5 & 5 \\
\hline CL (mm) & $2.1 \pm 0.05$ & $2.7 \pm 0.08$ & $3.6 \pm 0.13$ & $4.7 \pm 0.30$ & $6.3 \pm 0.35$ & $8.5 \pm 0.67$ & $11.6 \pm 1.16$ & $15.6 \pm 1.06$ \\
\hline $\mathrm{CW}(\mathrm{mm})$ & $1.5 \pm 0.04$ & $2.1 \pm 0.07$ & $2.9 \pm 0.14$ & $4.1 \pm 0.25$ & $5.6 \pm 0.43$ & $7.8 \pm 0.61$ & $10.8 \pm 1.07$ & $15.3 \pm 1.20$ \\
\hline POSL (mm) & $1.6 \pm 0.04$ & $2.08 \pm 0.05$ & $2.67 \pm 0.1$ & $3.64 \pm 0.17$ & $4.65 \pm 0.33$ & $6.37 \pm 0.41$ & $8.07 \pm 0.54$ & $10.75 \pm 0.5$ \\
\hline CW/CL & 0.71 & 0.77 & 0.80 & 0.87 & 0.88 & 0.92 & 0.93 & 0.98 \\
\hline CW/POSL & 0.93 & 1.00 & 1.09 & 1.12 & 1.20 & 1.22 & 1.34 & 1.42 \\
\hline Gonopores & Absent & Absent & Absent & Present & Present & Present & Present & Present \\
\hline \multicolumn{9}{|l|}{ Antennule } \\
\hline Endopod S & 2 & 3 & 3 & 4 & 4 & 5 & 6 & 6 \\
\hline Exopod S & 4 & 5 & 6 & 7 & 9 & 12 & $15-16$ & $17-18$ \\
\hline \multicolumn{9}{|l|}{ Antenna } \\
\hline Flagellum A & 6 & 8 & 8 & 11 & 13 & 17 & $18-20$ & $20-21$ \\
\hline \multicolumn{9}{|l|}{ Mandible } \\
\hline $\begin{array}{l}\text { Palp (s) } \\
\text { Maxilla }\end{array}$ & 0,5 & 1,5 & 1,8 & 5,9 & $8-9,12-13$ & $15-19,17$ & $23-25,17-18$ & $31-34,27$ \\
\hline $\begin{array}{l}\text { Maxilla } \\
\text { Scaphog (ms) }\end{array}$ & & & & & & & & \\
\hline $\begin{array}{l}\text { Scaphog (ms) } \\
\text { Maxilliped } 3\end{array}$ & 43 & 48 & $71-72$ & $88-93$ & 114-117 & $156-160$ & $190-210$ & $250-262$ \\
\hline Flagellum A & $\mathrm{nf}$ & $\mathrm{nf}$ & $3-4$ & $5-6$ & $8-9$ & $10-11$ & $13-14$ & $14-15$ \\
\hline
\end{tabular}

\section{Morphology of juvenile stages 2-8}

Figure 2 shows the sequential changes of the carapace shape throughout the stage sequence. Carapace measurements for each stage are given in Table
1. Data show that the carapace grows wider at each moult, and the $\mathrm{CW} / \mathrm{CL}$ ratio increases in the successive stages, becoming similar to the adult ratio in stage 7-8. The POSL shows a negative allometric growth $(\mathrm{b}=0.817 ; \mathrm{t}=34.79)$ while the $\mathrm{CW} / \mathrm{POSL}$ 


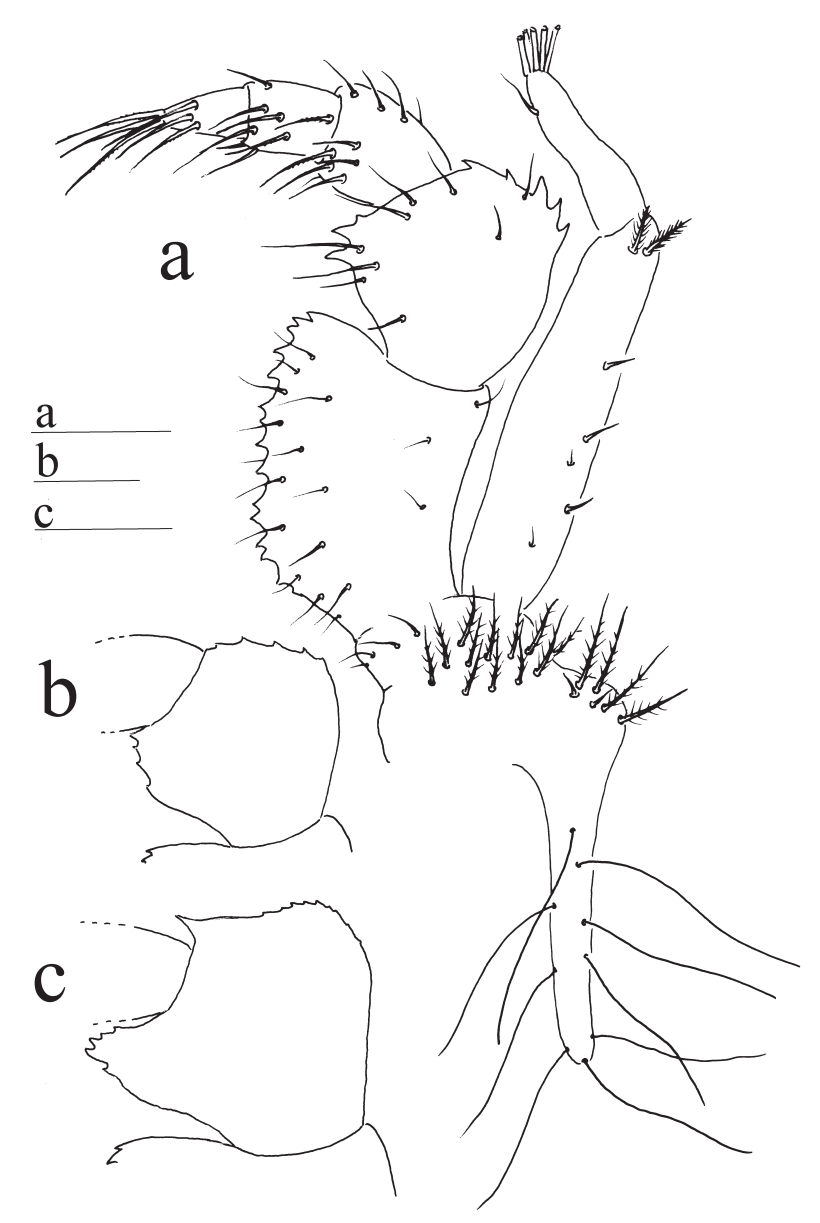

FIG. 6. - Maja brachydactyla Balss, 1922. Third maxilliped. a, first juvenile; $b$, juvenile 2 , detail of the merus; $c$, juvenile 6 , detail of the merus. Scale bars: $\mathrm{a}$ and $\mathrm{b}=200 \mu \mathrm{m} ; \mathrm{c}=500 \mu \mathrm{m}$.

ratio increases during the ontogenic development (Table 1, Fig. 13a). However, by juvenile stage 8 the CW/ POSL ratio has not yet reached the values of adult individuals $(\mathrm{CW} / \mathrm{POSL} \geq 2)$. The preocular, supraocular, hepatic, and branchial spines increase in size through the stage sequence (Fig. 2). Additional spines (secondary spines) appear from stages 7-8, resembling the adult spinulation pattern. The supraorbital spines show lateral spinulation from juvenile stage 2-3.

During juvenile ontogeny, the size and setation of the appendages increase. In addition, the number of segments of the antennular endopod and exopod and the antennal flagellum increases (Table 1). The distal segment of the exopod of the maxillipeds becomes flagellated from juvenile stage 3 , and the number of annulations, which show more differentiation distally, increases progressively with the development of the juveniles (Table 1). The merus of the third maxilliped becomes progressively subquadrate and is similar to that of the adult from juvenile stage 5-6 (Fig. 6).

Based on pleopod morphology, sexual differen-

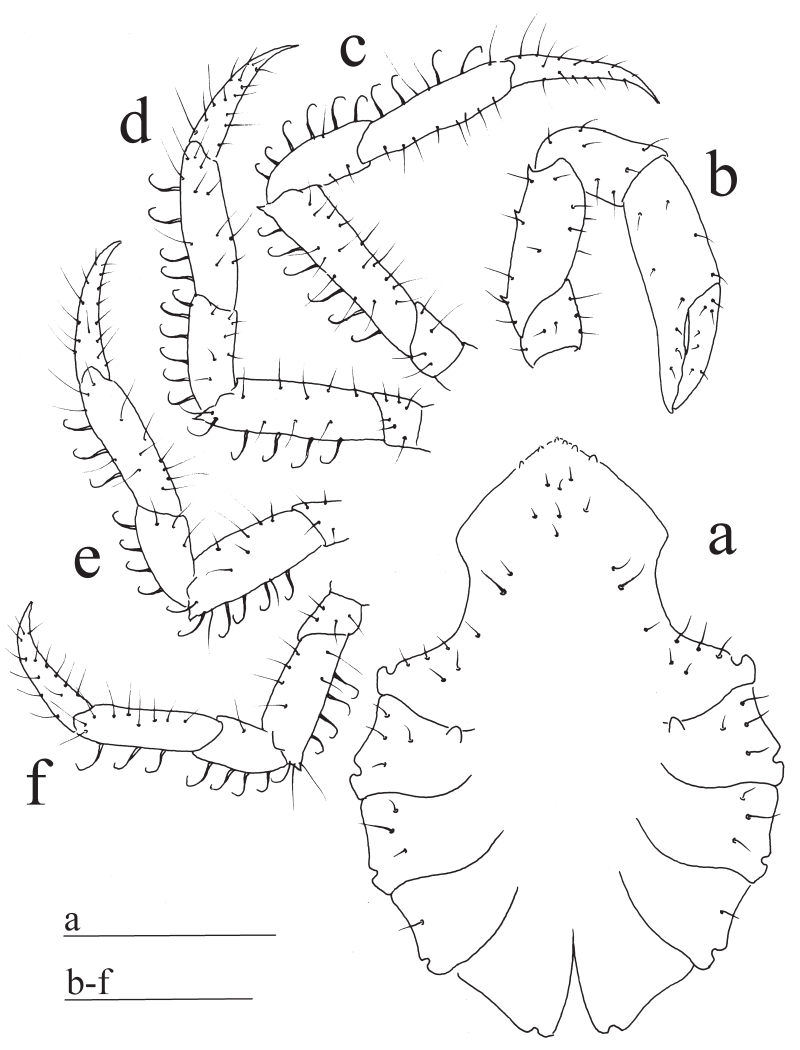

FIG. 7. - Maja brachydactyla Balss, 1922. First juvenile. a, sternum; b-f, pereiopods 1-5. Scale bars: a $=300 \mu \mathrm{m}$; b-f $=500 \mu \mathrm{m}$.

tiation becomes recognizable from stage 4 (Figs 9d,e and 11d,e). Four pleopod pairs on pleonites 2-5 and a pair of uropods on pleonite 6 are found in juvenile stages 1 and 2 (Figs 9a, b and 11a, b), those in juvenile stage 2 being slightly shorter than those in juvenile stage 1 . In juvenile stage 3 , pleopods are very minute and uropods are absent (Figs 9c and 11c). After moulting to juvenile stage 4, females retain the four appendage pairs (located on pleonites 2-5), which become biramous. However, in males the appendage pairs are reduced to two pairs, located on the first and second pleonites (Fig. 9d and 11e). In males, the first pleopod increases in length in successive stages, and a longitudinal groove is present in stage 7 (Fig. 12). The pleopods of females increase in length in successive juvenile stages and show setation from stage 78 (Figs 10 and 12). Gonopores are first visible in juvenile stage 4 in both sexes (Fig. 8). In juvenile males, gonopores closely resemble those of the adult, both in shape and location (coxa of pereiopod 5). In females, gonopores appear as a slight opening in the exuviae, on sternite 6 (Fig. 8 c,d). Sex-related differences can also be detected by examining the PW versus CL relationship (Fig. 13b): females show a positive relative growth pattern $(b=$ 

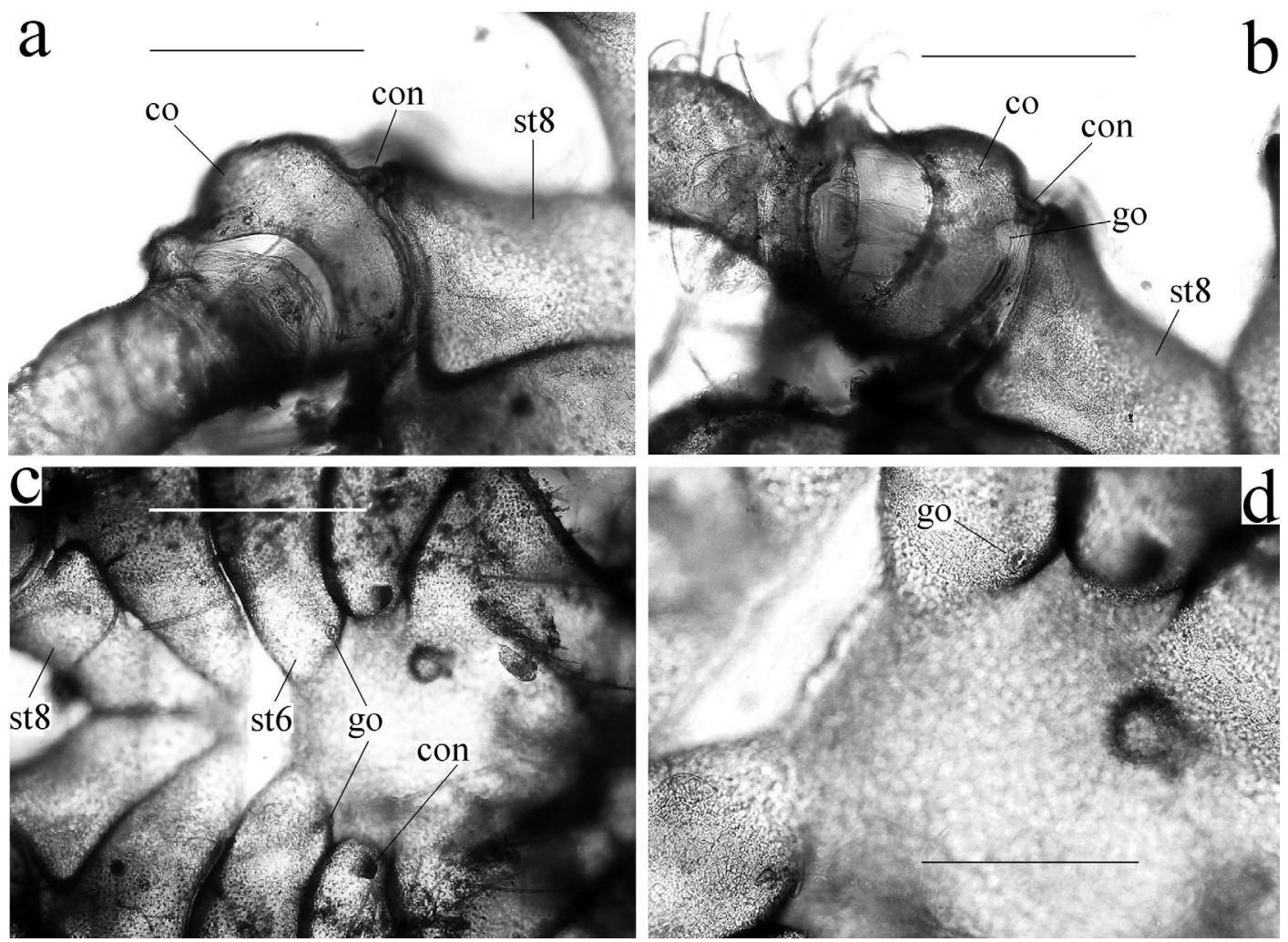

Fig. 8. - Maja brachydactyla Balss, 1922. Stage 4, gonopores. a, coxa of the pereiopod 5, female; b, coxa of the pereiopod 5, male; c, sternum of the female; $d$, detail of the gonopores of the female. Abbreviations: co, coxa; con, condyle; go, gonopore; st, sternite. Scale bars: $a, b=500$ $\mu \mathrm{m} ; \mathrm{c}=1 \mathrm{~mm}$.

$1.23 ; \mathrm{t}=-9.98)$ and males show an isometric growth pattern $(b=1.02 ; \mathrm{t}=1.779)$.

\section{DISCUSSION}

Lebour $(1927,1928)$ briefly described the early juvenile stages of Maja brachydactyla (as Maja squinado), specifically the morphology and size of the carapace in juvenile stages 1-3. However, her description does not correspond to $M$. brachydactyla. In fact, the carapace shape of the three juveniles that she attributed to Maja does not fit the description of majid species; it is probably the description of a portunid crab. Therefore, the present account is the first description of the morphology of early juveniles of the genus Maja, and it cannot be compared with Lebour's description.

Several important morphological characteristics used in the identification and classification of adults were not present in the first juvenile stage, but gradually appeared during early juvenile development: mainly the carapace shape and the presence and size of different spines and tubercles on the carapace. However, at the moment, we cannot conclude

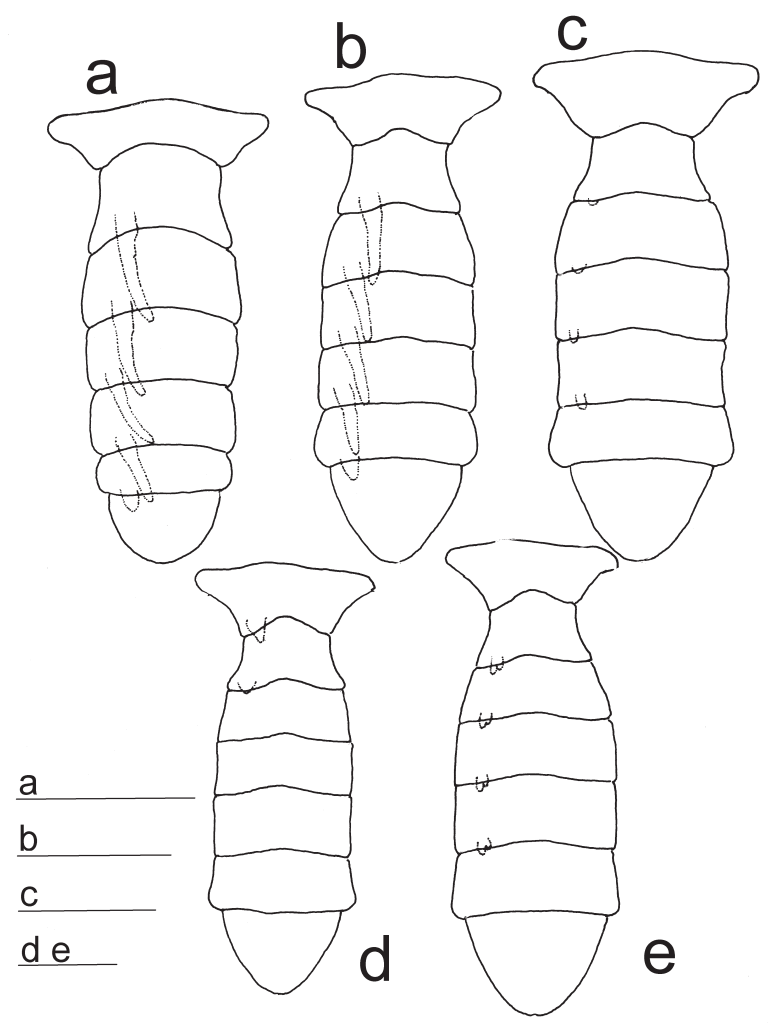

Fig. 9. - Maja brachydactyla Balss, 1922. Pleon. Juvenile stages 1-4. a-c, stages 1-3; d, stage 4, male; e, stage 4, female. Scale bars $=500 \mu \mathrm{m}$. 


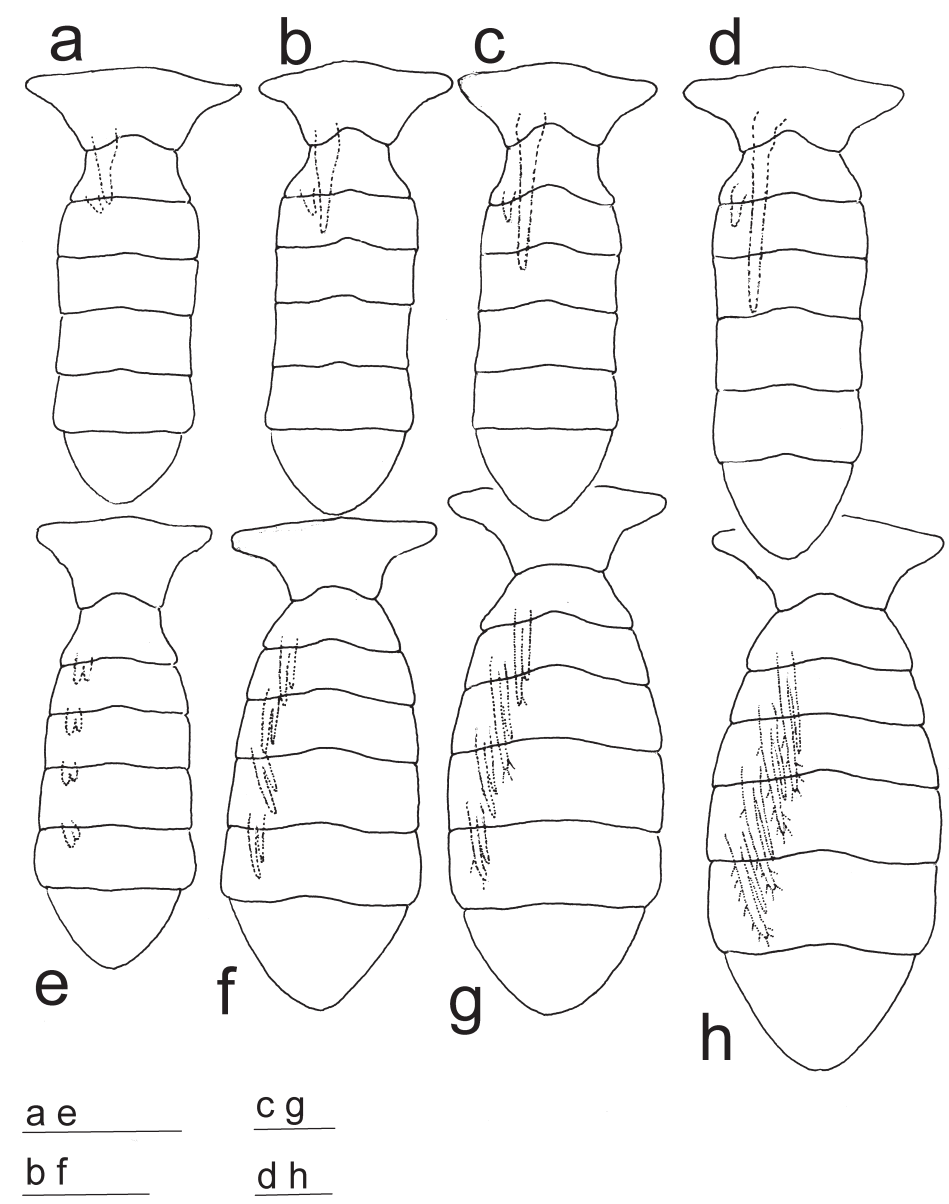

FIG. 10. - Maja brachydactyla Balss, 1922. Pleon. Juveniles stages 5-8. a-d, males; e-h, females. Scale bars $=1 \mathrm{~mm}$.

which juvenile stage may allow us to identify Maja brachydactyla from $M$. squinado, $M$. verrucosa and M. goltziana.

The morphology of the appendages of the first juvenile stage was similar to that of the megalopal stage (Clark, 1986; Guerao et al., 2008; Table 2). Although in general the number of setae was higher in the first juvenile stage, some appendages showed a few meristic differences, e.g. antennules, mandibles, maxillules and maxilles. In successive juvenile stages, the number of segments (exopod and endopod of the antennula and antennal flagellum), annulations (flagellated part of the exopod of the maxillipeds), and setation of the appendages increased (Table 1), which might be useful for differentiating the juvenile stages. These characteristics are important for the identification of juveniles of other studied brachyuran species (Bolla Jr. et al., 2008).

$M$. brachydactyla presents separate sexes, and morphological growth differences between sexes have been described in adults and sub-adults (Teissier, 1935; González-Gurriarán et al., 1995). Positive allometric growth of the female pleon has been associated with morphological adaptations for reproductive behaviour in adults, and specifically with the capacity for carrying eggs. Dimorphic abdominal growth (Fig. 10) was apparent from the fourth juvenile stage in $M$. brachydactyla, as was allometry between carapace length and abdominal width (Fig. 13b). Dimorphic abdominal growth has also been reported in juveniles of the other brachyurans species (e.g., Negreiros-Fransozo et al., 2003; Guimarães and Negreiros-Fransozo, 2005; Vinuesa and Ferrari, 2008).

Sexual differentiation in $M$. brachydactyla was also determined by the presence and position of the gonopores in juvenile stage 4 (Fig. 8) and the gradual modification of the pleopods in males into gonopods in juvenile stages 4-7 (Figs 11 and 12). Sexual differentiation also appears early in the ontogeny of other species of majoidean crabs (Ingle, 1977; Flores et al., 2002). In Pyromaia tuberculata (Lockington, 1877) (family Inachoididae) the development with undifferentiated sexes is much abbreviated: pleopod differentiation was found in juvenile stage 2 (Flores 

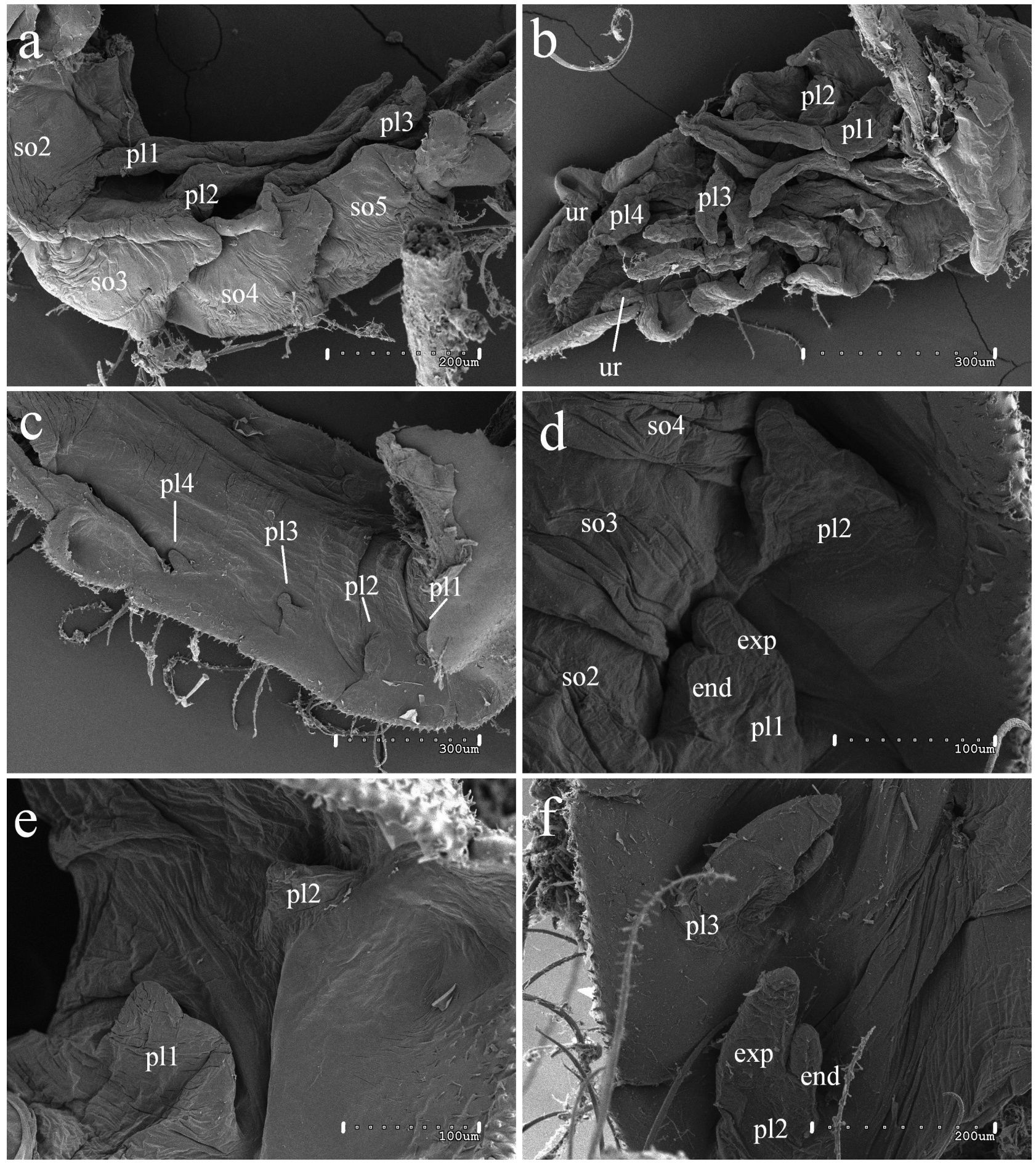

FIG. 11. - Maja brachydactyla Balss, 1922. Pleon. a, first juvenile; b, juvenile stage 2; c, juvenile stage 3; d, stage 4, female; e, stage 4, male ; f, stage 5, female pleopods 2 and 3. Abbreviations: exp, exopod; pl, pleopod; so, somite; ur, uropod. Scale bars: a and f $=200 \mu \mathrm{m}$; b and c $=$ $300 \mu \mathrm{m} ; \mathrm{d}$ and $\mathrm{e}=100 \mu \mathrm{m}$.

et al., 2002). However, gonopores were first visible in juvenile stage 4 , as in $M$. brachydactyla. In $P$. tuberculata no pleopods were found in the first juvenile stage, whereas in $M$. brachydactyla pleopods were present at that stage. Nevertheless, in the stage just before sexual differentiation (stage 3) pleopods (present on pleonites 2-5) were vestigial. In Inachus dorsettensis (Pennant) (family Inachidae) sexes could be distinguished from the third juvenile stage (Ingle, 1977): the male had pleopods on segments 

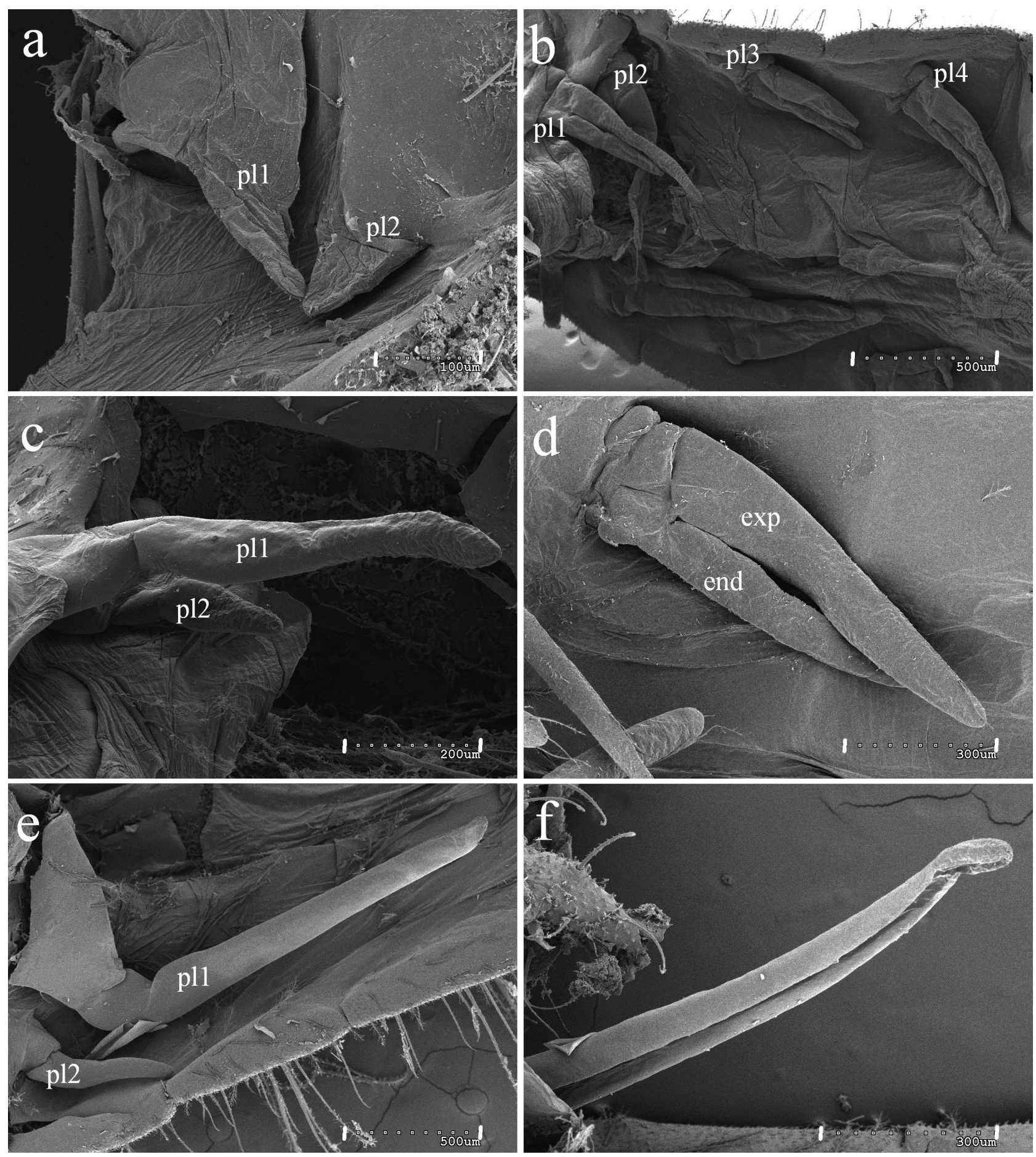

FIG. 12. - Maja brachydactyla Balss, 1922. Pleon. a, pleopods of the male, stage 5; b, stage 6, female; c, stage 6, male; d, stage 7, female; e, stage 7, pleopods of the male; f, stage 7, first pleopod of the male. Abbreviations: end, endopod; exp, exopod; pl, pleopod. Scale bars: a = 100 $\mu \mathrm{m} ; \mathrm{b}$ and $\mathrm{e}=500 \mu \mathrm{m} ; \mathrm{c}=200 \mu \mathrm{m} ; \mathrm{d}$ and $\mathrm{f}=300 \mu \mathrm{m}$.

1 and 2 , and on segment 3 , but here they were very minute and vestigial. In I. dorsettensis, the pleopods on segments 2-5 were reduced to minute buds in the second juvenile stage, which is also one juvenile stage before sexual differentiation (one juvenile stage earlier than in M. brachydactyla).
Other studied brachyuran species belonging to the different superfamilies show an abbreviated juvenile (undifferentiated sexes) development similar to the majoidean species (e.g. Grapsidae, Plagusiidae, Portunidae): the sexes in Callinectes sapidus (Rathbun, 1896), Rhithropanopeus harrisii (Gould, 1841), 

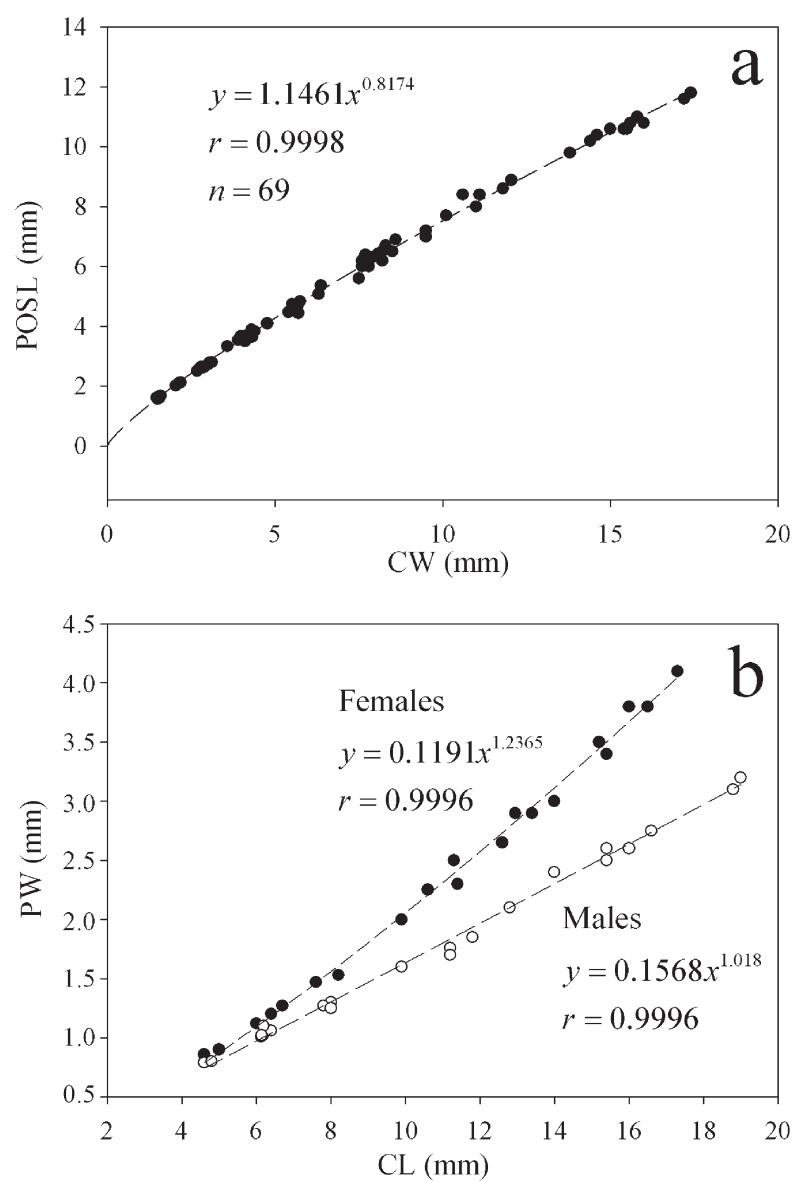

FIG. 13. - Maja brachydactyla Balss, 1922. a, relationship between POSL and CW. b, variation of pleon width (PW) according to carapace size (CL) in males and females from juvenile stage 4.

Menippe mercenaria (Say, 1818) (Payen, 1974), Carcinus maenas (Linnaeus, 1758) (Shen, 1935), Pachygrapsus tranversus (Gibbes, 1850) (Flores et al., 1998) and Calappa tortugae Rathbun, 1933 (Negreiros-Fransozo et al., 2007) can be distinguished in juvenile stage 2; in Hepatus pudibundus (Herbst, 1785) (Hebling and Rieger, 2003) and Neohelice (=Chasmagnathus) granulata Dana, 1851 (Rieger and Nakagawa, 1995) sexes can be distinguished in juvenile stage 3; in Eriphia gonagra (Fabricius, 1781), Eurypanopeus abbreviatus (Stimpson, 1860) (Fransozo and Negreiros-Fransozo, 1987), Panopeus herbstii H. Milne-Edwards, 1834 (Hebling et al., 1982), Menippe nodifrons (Stimpson, 1859) (Fransozo et al., 1988), Cyrtograpsus angulatus Dana, 1851 (Rieger and Beltrão, 2000), Eurytium limosum (Say, 1818) (Guimarães and NegreirosFransozo, 2005) and Callinectes ornatus Ordway, 1863 (Bolla Jr. et al., 2008) and Leptodius exaratus (H. Milne-Edwards, 1834) (Lwin, et al., 2007), they can be distinguished in juvenile stage 4 . On the other
TABLE 2. - Morphometrical and morphological comparison between megalopa stage and first juvenile of Maja brachydactyla. Abbreviations: a, aesthetascs; s, setae; sp, spines; ssp, stout short spines; end, endite; CL, carapace length; CW, carapace width.

\begin{tabular}{|c|c|c|}
\hline Feature & $\begin{array}{c}\text { Megalopa } \\
\text { (Guerao et al., 2008) }\end{array}$ & $\begin{array}{l}\text { First juvenile } \\
\text { (present study) }\end{array}$ \\
\hline $\mathrm{CL}(\mathrm{mm})$ & $1.67 \pm 0.07$ & $2.1 \pm 0.05$ \\
\hline $\mathrm{CW}(\mathrm{mm})$ & $0.64 \pm 0.02$ & $1.5 \pm 0.07$ \\
\hline Carapace (sp) & absent & present \\
\hline Antennule $(a+s)$ & $0,8+1,4+0,0+1$ & $0,5+1,4+0,0+3-4$ \\
\hline Antenna & & \\
\hline Flagellum (s) & $0,4,3$ & $0,1,1-2,0,3,2$ \\
\hline \multicolumn{3}{|l|}{ Mandible } \\
\hline Palp (s) & 4 & 5 \\
\hline \multicolumn{3}{|l|}{ Maxillule } \\
\hline Coxal end (s) & $10-11$ & 10 \\
\hline Basial end (s) & $18-19$ & 18 \\
\hline \multicolumn{3}{|l|}{ Maxilla } \\
\hline Coxal end (s) & $5+5$ & $5+5$ \\
\hline Basial end (s) & $6+6$ & $6+6$ \\
\hline Scaphognathite (s) & $40-41+5$ & $42-43+6-7$ \\
\hline \multicolumn{3}{|l|}{ Maxilliped 1} \\
\hline Coxal end (s) & 7 & $9-13$ \\
\hline Basial end (s) & 12 & $20-24$ \\
\hline Epipod (s) & 5 & $13-16$ \\
\hline \multicolumn{3}{|l|}{ Maxilliped 2} \\
\hline Endopod (s) & $0,0,1,3,5$ & $1,2,1,6,7-8$ \\
\hline Exopod (s) & 0,4 & $5-6,7$ \\
\hline \multicolumn{3}{|l|}{ Maxilliped 3} \\
\hline Endopod (s) & $11,5-6,5,6,5$ & $21-19,6-9,10,9,6$ \\
\hline Exopod (s) & 0,4 & $6-7,6$ \\
\hline Epipod (s) & $8-7+3$ & $9+4-6$ \\
\hline \multicolumn{3}{|l|}{ Pereiopods 1-5 } \\
\hline Coxa $(\mathrm{sp})$ & $0,1,1,1,0$ & $0,0,0,0,0$ \\
\hline Ischium (sp) & $1,1,1,0,0$ & $0,0,0,0,0$ \\
\hline Merus (sp) & $0,0,0,0,0$ & $3,1,1,1,1$ \\
\hline Dactylus (ssp) & $0,2,2,3,3$ & $0,0,0,0,0$ \\
\hline Sternum (s) & 6 & $>35$ \\
\hline \multicolumn{3}{|l|}{ Pleopods } \\
\hline Exopod (s) & $12,11-12,12,10-11$ & $0,0,0,0$ \\
\hline
\end{tabular}

hand, sexual differentiation in Sesarmid crabs seems to follow a different pattern: smaller recruits, long juvenile development, and delayed sexual maturity. As a specific example, Sesarma rectum (Randall, 1840) pleopod differentiation does not take place at least until juvenile stage 12 (Fransozo, 1987).

Due to the lack of studies on juvenile development, it is difficult to define diagnostic characters of different brachyuran families. However, these features are of great importance to provide information for ecological and phylogenetic investigations.

\section{ACKNOWLEDGEMENTS}

Financial support was provided by the Ministry of Science and Research to GG (post-doctoral fellowship; INIA) and GR (Ramón y Cajal contract). Bench fees were funded by JACUMAR (REPES project) to GR. The authors would like to thank Jose Manuel Fortuño of the ICM (CSIC) for his assist- 
ance in SEM study and Glòria Macià, Miriam Matas, Isolda Banus, Sandra Molas and Joaquín Canoura for their support as hatchery and laboratory technicians at the IRTA, Sant Carles de la Ràpita.

\section{REFERENCES}

Andrés, M., A. Estévez and G. Rotllant. - 2007. Growth, survival and biochemical composition of spider crab Maja brachydactyla Balss, 1922 (Decapoda: Majidae) larvae reared under different stocking densities, prey: larva ratios and diets. Aquaculture, 273: 494-502.

Bolla Jr., E.A., M.L. Negreiros-Fransozo and A. Fransozo. - 2008. Juvenile development of Callinectes ornatus Ordway, 1863 (Crustacea: Decapoda: Portunidae), from megalopae obtained in the neuston. Zootaxa, 1788:1-20.

Clark, P.F. - 1986. The larval stages of Maja squinado (Herbst, 1788) (Crustacea: Brachyura: Majidae) reared in the laboratory. J. Nat. Hist., 20:825-836.

d'Udekem d'Acoz, C. - 1999. Inventaire et distribution des crustacés décapodes de l'Atlantique nord-oriental, de la Méditerranée et des eaux continentales adjacentes au nord de $25^{\circ} \mathrm{N}$. Museé National d'Histoire Naturelle, Paris.

Felder, D.L., J.W. Martin and J.W. Goy. - 1985. Patterns in early postlarval development of decapods. In: A.M. Wenner (ed.), Larval Growth, pp. 163-225. F. Schram (series ed.), Crustacean Issues 2. Balkema Press, Rotterdam.

Felgenhauer, B.E. - 1987. Techniques for preparing crustaceans for scanning electron microscopy. J. Crustac. Biol., 7(1): 71-76.

Flores, A.A.V., M.L. Negreiros-Fransozo and A. Fransozo. - 1998. The megalopa and juvenile development of Pachygrapsus transversus (Gibbes, 1850) (Decapoda, Brachyura) compared with other grapsid crabs. Crustaceana, 71(2): 197-222.

Flores, A.A.V, F.P.L. Marques and M.L. Negreiros-Fransozo. 2002. Postlarval stages and growth patterns of the spider crab Pyromaia tuberculata (Brachyura, Majidae) from laboratoryreared material. J. Crustac. Biol., 22(2): 314-327.

Fransozo, A. - 1987. Desenvolvimiento dos estágios juvenis de Sesarma (Holometopus) rectum Randall, 1840 (Decapoda, Grapsidae) obtidos em laboratório. Naturalia, 11/12: 77-87.

Fransozo, A. and M.L. Negreiros-Fransozo. - 1987. Morfologia dos primeros estágios juvenis de Eriphia gonagra (Fabricius, 1781) e Eurypanopeus abbreviatus (Stimpson, 1860) (Crustacea, Decapoda, Xanthidae), obtidos em laboratório. Papéis Avulsos Zool., 36(22): 257-277.

Fransozo, A., M.L. Negreiros-Fransozo and C.M. Hiyodo. - 1988. Développement juvénile de Menippe nodifrons Stimpson, 1859 (Crustacea, Decapoda, Xanthidae) au laboratoire. Rev. Hydrobiol. Trop., 21(4):297-308.

González-Gurriarán, E., J. Freire, J. Parapar, M.P. Sampedro and M. Urcera. - 1995. Growth at moult and moulting seasonality of the spider crab, Maja squinado (Herbst) (Decapoda:Majidae) in experimental conditions: implications for juvenile life history. J. Exp. Mar. Biol. Ecol., 189: 183-203.

Guerao, G., M. Rufino and P. Abelló. - 2003. Morphology of the larval and first juvenile stages of the spider crab Lissa chiragra (Brachyura: Majidae: Pisinae). J. Nat. Hist., 37(6): 647-671.

Guerao, G., K. Anger and C. D. Schubart. - 2007. Larvae and firststage juveniles of the American genus Armases (Brachyura: Sesarmidae): a morphological description of two complete developments and one first zoeal stage. J. Nat. Hist., 41 (2932): 1811-1839.

Guerao, G., E. Pastor, J. Martin, M. Andrés, A. Estévez, A. Grau, J. Duran and G. Rotllant. -2008. The larval development of Maja squinado and M. brachydactyla (Decapoda, Brachyura, Majidae) described from plankton collected and laboratory-reared material. J. Nat. Hist., 42 (33-34): 2257-2276.

Guimarães, F.J and M.L. Negreiros-Fransozo. - 2005. Juvenile development and growth patterns in the mud crab Eurytium limosum (Say, 1818) (Decapoda, Brachyura, Xanthidae) under laboratory conditions. J. Nat. Hist., 39(23): 2145-2161.
Hebling, N.J., A. Fransozo and M.L. Negreiros-Fransozo. - 1982. Desenvolvimiento dos primeiros estágios juvenis de Panopeus herbstii H. Milne-Edwards, 1834 (Crustacea, Decapoda, Xanthidae), criadas em laboratório. Naturalia, 7: 177-188.

Hebling, N.J. and P.J. Rieger. - 2003. Desenvolvimiento juvenil de Hepatus pudibunus (Herbst) (Crustacea, Decapoda, Calappidae), em laboratório. Rev. Bras. Zool., 20(3): 531-539.

Ingle, R.W. - 1977. The larval and post-larval development of the scorpion spider crab, Inachus dorsettensis (Pennant) (Family: Majidae), reared in the laboratory. Bull. Br. Mus. Nat. Hist. (Zool.), 30: 331-348.

Ingle, R.W. - 1992. Larval stages of Northeastern Atlantic Crabs. An Illustrated Key. Chapman and Hall, London.

Ingle, R.W. and A.L. Rice. - 1984. The juvenile stages of eight swimming crab species (Crustacea: Brachyura: Portunidae); a comparative study. Bull. Br. Mus. nat. Hist. (Zool.), 46: 345354.

Lebour, M.V. - 1927. Studies of the Plymouth Brachyura. I. The rearing of crabs in captivity, with a description of the larval stages of Inachus dorsettensis, Macropodia longirostris and Maja squinado. J. Mar. Biol. Ass. U.K., 14: 795-820.

Lebour, M.V. -1928. The larval stages of the Plymouth Brachyura. Proc. Zool. Soc. London, 2: 473-560.

Luppi, T.A. and E.D. Spivak. - 2003. Postembryonic development of Pyromaia tuberculata (Lockington, 1877): a review of larval and postlarval morphology. Sci. Mar., 67(2): 201-214.

Lwin, T.T., W. Doi, M. Yokota, C.A. Strussmann and S. Watanabe. - 2007. Juvenile morphology of the xanthid crab Leptodius exaratus (H. Milne-Edwards, 1834) (Decapoda: Brachyura), with notes on the appearance of sexual dimorphism. Inv. Repr. Dev., 50(4): 191-201.

Negreiros-Fransozo, M.L., K.D. Colpo and T.M. Costa. - 2003. Allometric growth in the fiddler crab Uca thayeri (Brachyura, Ocypodidae) from a subtropical mangrove. J. Crustac. Biol., 23(2): 273-279.

Negreiros-Fransozo, M.L., E.L. Wenner, D.M. Knott and A. Fransozo. - 2007. The megalopa and early juvenile stages of $\mathrm{Ca}$ lappa tortugae Rathbun, 1933 (Crustacea, Brachyura) reared in the laboratory from South Carolina neuston samples. Proc. Biol. Soc. Wash., 120(4): 469-485.

Neumann, V. - 1998. A review of the Maja squinado (Crustacea: Decapoda: Brachyura) species-complex with a key to the eastern Atlantic and Mediterranean species of genus. J. Nat. Hist., 32: $1667-1684$.

Paula, J. - 1985. The first zoeal stages of Polybius henslowi Leach, Maja squinado (Herbst), Pachygrapsus marmoratus (Fabricius) and Uca tangeri (Eydoux) (Crustacea, Decapoda, Brachyura). Arq. Mus. Boc. (Série B), 2: 137-147.

Payen, G. - 1974. Morphogenèse sexuelle de quelques Brachyoures (Cyclométopes) au cours du développement embryonnaire, larvaire et postlarvaire. Bull. Mus. Natl. Hist. Nat. (3n série), 209, Zool. 139: 202-261.

Rieger, P.J. and C. Nakagawa. - 1995. Desenvolvimiento juvenil de Chasmagnathus granulata Dana, 1851 (Crustacea, Decapoda, Grapsidae) em laboratório. Nauplius, 3: 59-74.

Rieger, P.J. and R. Beltrão. - 2000. Desenvolvimiento juvenil de Cyrtograpsus angulatus Dana (Crustacea, Decapoda, Grapsidae), em laboratório. Rev. Bras. Zool., 17(2): 405-420.

Schlegel, C. - 1911. Sur le développement de Maïa squinado Latr. Compte Rendu Hebdomadaire des Séances Acad. Sci. Paris, 153: 480-482.

Shen, C.J. - 1935. An investigation of the post-larval development of the shore-crab Carcinus maenas, with the special reference to the external secondary sexual characters. Proc. Zool. Soc. Lond., 1935: 1-33.

Teissier, G. - 1935. Croissance des variants sexuels chez Maia squinado L. Trav. Sta. Biol. Roscoff, 13: 93-130.

Vinuesa, J.H. and L. Ferrari. - 2008. Postlarval development of Halicarcinus planatus females (Crustacea: Decapoda: Hymenosomatidae) in the estuary of the Deseado River, Argentina. Sci. Mar., 72(1):127-132,

Scient. ed.: J.A. Cuesta.

Received October 14, 2008. Accepted February 26, 2009.

Published online September 8, 2009. 